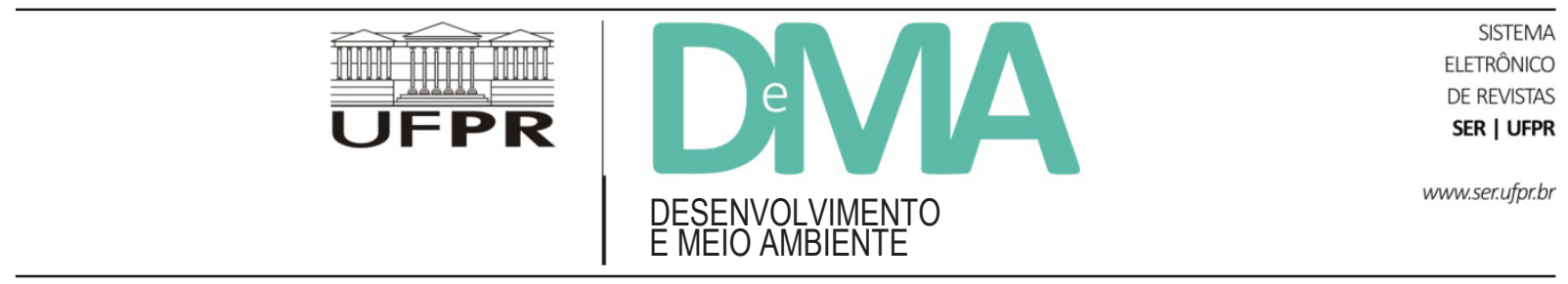

\title{
Depoimento de Rodolfo José Angulo ${ }^{1}$
}

Magda

Conheci a Magda por causa do destino, como genialmente escreveu J.L. Borges²: tal es el nombre que aplicamos a la infinita operación incesante de millares de causas entreveradas ${ }^{2}$. Não lembro exatamente quando conheci a Magda, foi nos anos 80 , quando a redemocratização promovia o retorno dos exilados e atiçava seu desejo de construir um Brasil novo, mais justo e mais solidário. Quando percebi, já éramos amigos íntimos. Magda queria trazer para o Brasil os novos debates que ocorriam na França sobre meio ambiente de desenvolvimento e, sobretudo, aplicar estes conceitos em práticas que favorecessem os mais pobres. Sempre sua atuação teve duas vertentes muito fortes: a acadêmica e a ação política e social. A Magda era incansável, uma força da natureza, nas palavras de sua amiga Angela.

Tenho certeza que sem a Magda não existiria o MADE.

Neste início do programa não existiam muitos limites entre o profissional e o privado, éramos colegas e amigos, reuniões em casa, jantares, churrascos, bares, rodas de samba. Amizades fortes se consolidavam e um fluxo constante de colaboradores se estabeleceu entre Brasil e França. Havia, na época, grande interesse pelo social, pensávamos que era possível construir um mundo mais solidário e mais fraterno e a Magda estava, incansável, no centro desta construção.

\footnotetext{
${ }^{1}$ Doutor em Geologia. Professor do Departamento de Geologia da UFPR. Atualmente Professor Sênior dos programas de pós-graduação em Geologia (PosGeol) e em Meio Ambiente e Desenvolvimento (PPGMADE). Membro da equipe nomeada para a criação do MADE em 1992 e primeiro coordenador do Programa (outubro/1993 a janeiro/1997).

${ }^{2}$ Borges J. L. El impostor inverosímil Tom Castro. In: Borges J. L. Historia universal de la infamia. Buenos Aires: Emecé Editores S.A., 1954, p.31-40.
} 